\title{
DANCING TO CREATE ALTERNATIVE AND HEALING SPACES IN MIRA NAIR FILMS
}

Jorge Diego Sánchez

CUID (UNED, Spain)

\section{Abstract:}

This paper studies how Nair represents female characters that empower themselves using dance elements from the South Asia Subcontinent performing arts tradition to subvert the British Empire historical forms of colonial (and neo-colonial) domination based on race and gender.

\section{KEY WORD:}

Mira Nair, dance, South Asian Subcontinent, film. 
Dance is subversive because it entails a communion and transformation among performers, audience and the space where the artistic experience takes place. It is in this sense that dance, as part of the holistic performing languages used in the hybrid narratives from South Asian tradition, facilitates an encounter with the divine power that every human being has within. This paper studies how the Indian film director Mira Nair represents female characters that empower themselves and come to terms with the cultural hybridity of the diaspora space they live in through dance. The study will show how dance allows female characters to struggle against the male domination they suffer both in the diaspora and in the homelands. The methodological approach of this essay unveils why dance creates alternative and healing spaces in the selected films by Nair through Gender, Cultural and Postcolonial Studies. These threefold slant allows me to contextualise Mira Nair's films within the South Asian performing arts tradition therefore ruining the hopes of those readers who expected a Bollywood exotica of Orientalist women and cultures. ${ }^{1}$ Secondly, it enacts a reading of the dance scenes in Nair's selected films as subversive corollaries that show how Mira Nair subverts traditionally chauvinist and racist clichés about the role expected of Indian women both in the homelands and in the diaspora and the homelands.

\section{DANCE IN THE SOUTH ASIAN SUBCONTINENT PERFORMING ARTS TRADITION}

Dance is a part of the holistic performing languages used in the hybrid narratives from South Asian performing arts tradition to facilitate an encounter with the divine power that every human being has within as the same time as to challenge the colonial (and now neo-colonial) British attempts to conceal it. Accordingly, dance is subversive because it entails a communion and transformation among performers, audience and the space where the artistic experience takes place and from where women have been stereotyped, restricted or limited. It is against these burdens experienced by women that female characters in Nair's films derogate patriarchal structures and neo-colonial stereotyping through the use of dance in specific moments of her films. Then, it is crucial to understand why the survival of South Asian performing arts and dance is important to recognise how dance allows female characters in Nair's films to find alternative and healing spaces from where to struggle against the male domination they suffer both in the diaspora and in the homelands at the same time as they negotiate their roots with the new routes that lay ahead of them.

Dance in the South Asian Subcontinent (India, Pakistam, Bangladesh, Nepal, Bhután and Sri Lanka) is part of the Natya Veda, the fifth Sacred Scripture, that recognises that

1 Life and work of Mira Nair are paradigmatic as a feminist pioneer in Film and Postcolonial studies. TO know a bit more about her check John Kenneth Nuir's Mercy in Her Eyes. The Films of Mira Nair (2006) and Jorge Diego Sánchez's "Hybrid Cinemas and Narratives: Gender Representations in Women's Cinema of the South Asian Diaspora" (2015) performing arts are a religious composite that gives meaning to the daily life. Religious here in the Latin sense of "re-ligare" because it allows the communication with oneself, the society and God itself throughout the exploration and experimentation of the manifestation of the divine within every human. Performing arts link body, mind and soul because they connect the performer, audience and the divine essence the same time. It is so that South Asian performing arts, as retailed in the sacred text of the Natyasastra, intertwine music and dance altogether defining the performing arts experience in South Asian tradition as a holistic participation of different languages and genres.

Bharata Muni assembled a treaty of thirty six or thirty seven ${ }^{2}$ chapters ${ }^{3}$ on performing arts issues in Sanskrit around the $2^{\text {nd }}$ century BD ${ }^{4}$ (Rangacharya xv; González Cruz 30). His objective was that of collecting the plurality of the performing arts to guarantee some unity in diversity for performing arts practitioners. In other words, he compiled the diversity of "a miscellany of techniques, features, instruments and artistic practices for music, dance and acting techniques for the construction and performance of a play" (Rangacharya i) in the unity of a single treaty.

Natyasastra includes different theoretical and practical chapters such as "The Worship of the Stage and of the Gods, The Acting of the Subordinate Parts of the Body" (Chapter VIII), "The Stage Walk of Characters" (Chapter XIII), "The Metrical Patterns" (Chapter XVI), "Rules on the Use of Languages" (Chapters XVIII and Chapter XIX), "The Outward Characterization of Men and Women" (Chapter XXV), "The Success of a Production" (Chapter XXVII), "The Instrumental Music" (XXVII) or "Distribution of Roles" (Chapter XXXV). Thus, Natyasastra offers a compendium of technical and artistic tools for performers to enhance communication between performer and audience during the performing arts act. Iván González Cruz, first translator of the whole Natyasastra into Spanish in 2013, states that Natyasastra entails the essence of performing arts poetics (1) and Spanish scholars Chantal Maillard and Óscar Pujol contextualise Bharata's work as the treaty that ensures the composition and performance of a true theatrical experience created by both performers and audience (8). Theatrical experience is understood as encompassing both the audience and the performer together, without distinctions. For that reason, Natyasastra groups performing arts practices that relish empathy between performer and audience in

2 Some editions encompass the thirty six original chapters whereas others gather latter addition that did not appear in the original treaty.

3 The titles of the Chapters are taken from Rangacharya's edition (2010).

4 Natyasastra is likely to have been shared orally since the 7th or 8th century BC (Maillard and Pujo 7; Rangacharya iii) and probably written down not by Bharata but by his disciples, namely, Kohala Vâtsya, Sân, dilya and Dattila, who are mentioned also as children of the sage (Rangacharya xvii). 
order to promise the freedom and participation of both in the experience facilitated by the performance itself.

Women are, in the pages of the Natyasastra, presented as actresses that are the vehicle to covey the meaning that the gods and the priests, all male, determine. Women are then a subordinated agent that, as Rabindra Tagore sketched in Natir Puja (1926), depends on the structures that religion, family and political life imposed upon themselves. Women were only the performers and the tellers of the stories were male. The conductors were men although the divine power is represented as both female and female (the Sanskrit concept of Ardhanariswara). According to South Asian tradition, dance is the purest representation of the primitive essence of the human being (Sarabhai 1-43; Winton-Henry 160). Vedanta tradition describes how the world is originated, maintained and destroyed to initiate itself once again through dance by the god Shiva in Shiva's Tandav (The Dance of Shiva Nataraj). Tandav is a powerful and energetic dance where Shiva spins around himself to illustrate the creation, evolution, conservation and destruction as the necessary means that set anew a further evolution for mankind (Massey 8). One should always remember that The dance of Kali, female divine energy or Goddess, reflects Shiva's origin of the world through dance as she destroys to bring life anew. Nevertheless, this part has been ostracised.

Dance should be understood never in opposition to any of the other performing arts but containing them all. As Helen Gilbert states: "[Western] critical drama has frequently defined dance and dramatic dialogue in opposition to each other through epistemologies which emphasize the Renaissance mind/body dichotomy" (133). As a consequence, and as Gilbert mentions, dance has occupied a "subordinate" position as a "universal sign" having been denied to its own "historical, geographical, and sociocultural specifity [sic] of dance" (133). For instance, a study about dance that departs from a binary opposition theatre versus dance ignores that, as Gilbert points out, dance is "a way of representation, . . . a site of cultural negotiation, . . . a loci of resistance to hegemonic, ... [a] counter-discourse of the body and its signifying practices and dance abilities to spatialize" (135). In other words, the interconnected nature of dance and theatre can be seen as fact and as Italian playwright Eugenio Barba states: "a rigid distinction between dance and drama risks drawing the actor towards a denial of the body" (12).

In colonial times, South Asian female dancers were defined as inhabiting temples as courtesans and priests' prostitutes. Their dance form was reduced to a mere decorative effect and they were invited to dance at colonial officers' events in an exotic fashion that can be illustrated in, for instance, the Orientalist paintings by colonial Indian painter Raja Ravi Varma (1848-1906), who used Western painting techniques to detail Indian life. These remarks recalled the rejection and stereotyping that Bharatanatyam and the dance form had had in the South Asian Subcontinent during Medieval times as it had been reduced to a simple aim of decoration therefore ignoring its much more profound meaning (Morcom 1-44; Vatsyayan 5; Roychowdhury 2014; Dinesh and Ramanathan 12). Maratha King Saraboji II in Tamil Nadu (1798-1832) recovered and recognised the true holistic performing practice of the form because it moved, according to US dance ethnographer Deidre Sklar, "toward all aspects of life ... in the contextual web of social relationships, environment, religion, aesthetics, politics, economics, and history" (6). However, the arrival of the East India Company in Indian coasts in the eighteenth century and the following British rule soon neglected the practice of the South Asian regional arts. Anna Morcom expresses how, for instance, bharatanatyam "was excluded in an absolute sense in modern colonial India" (3). These ideas would then be inforced by the British colonial occupation for, as dancer Ananya Chatterjea highlights, "conceptualisations for classical Indian female dancers define them as either hieratic classical pieces of ethnic museum or mere exotic Bollywood dancers" (2011b). Nevertheless, Maratha King Saraboji II's former efforts were important for the anticolonial fight lately played by Indian theosophist, dancer, actress and writer Rukmini Devi Arundale (1904-1986) who fostered, in 1936 and in Madras, the school of regional dance and music Kalakshetra. Arundale's school was an effort to teach and promote regional studies to fight against the devastating influence of the British Empire's attempt to make South Asia's own tradition disappear (Morcom 25; Roychowdhury 2014).

Arundale's commitment was very important because she enhanced the performance of bharatanatyam's own language as told in Natyasastra as well as her positioning male bharatanatyam performers back on stage (Balaswarati 5). Later, Arundale, together with Indian freedom fighter and cultural activist E. Krishna Iyer (1897-1968), discarded those postures included in bharatanatyam during Medieval Ages that mostly added certain gestures only to reduce bharatanatyam as a dance practice that was simply aimed at creating an erotic meaning.

The British Empire, contrarily, kept reducing bharatanatyam as the practice of merely erotic gestures. Janet O'Shea states how bharatanatyam was reduced to "a static piece of museum, an exotic form of art" (ix). It was then at this moment that Arundale's foundation of a parallel school contested British colonising cultural hegemony to recover and maintain the true expression of bharatanatyam as a resisting, artistic and cultural practice in the Subcontinent during the British occupation. And it continued until our contemporary day, with the re-enactment of the form in diaspora. So, there is an inherent subversive power within the use of dance in Nair's selected movies because it means a rejection of the British Empire and a possibility to use dance to offer a rewriting of both history and stories of colonial looting, patriarchal ruling, 
racial superiority and feminist obscuration that had constrained the South Asian forms of performance and expression in both the homelands and in the diaspora.

\section{BUILDING HEALING SPACES IN NAIR'S FILMS}

Nair's films provide hybrid narratives that use elements from the South Asian performing arts with a subversive endeavour that challenges the interlocking systems of domination historically based on race and gender. Trinidadian actor, director and scholar Rawle Gibbons recognise this postcolonial objective because, in his own words, "the relation of art and tradition is a powerful means to decolonise" (179). Mira Nair uses elements from South Asian dance as a challenging artistic language because it entails a communion and transformation among performers, audience and the space where the artistic experience takes place. It is in this sense that the history of the South Asia Southern dance style bharatanatyam challenged the British colonial history that somehow tried to ostracise and stereotype the form. Besides, dance enables a revolution of politics, race and gender because, as Gilbert and Tompkins assert, "dance is particularly important, not only as a celebration of the physical (as in much western theatre) but also as a performed statement of transformation or possession" (62). It is therefore this possibility of change which confirms that dance has a transformative power to facilitate a new definition and opportunities for characters and, so, for performers and audience.

Helen Gilbert recognises that a postcolonial study of dance must focus on "resistance politics [as well as] on movement as part of identity formation/recuperation and spatial re-orientation" (138). Therefore, Mira Nair 's postcolonial commitment finds in this narrative of dance a combative and ecstatic attitude to foster a new identity and its representation for South Asian women on screen. For instance, in Monsoon Wedding, Nair decides to make the whole Verma family confront its cultural, economic, social and moral differences through the dance scene choreographed by Ayesha to the song "Chunari, Chunari" (1h 23'12"-1h 27'40"). Ayesha is Aditi's cousin and she is shown as a combative woman throughout the whole movie. Previously, she has led the Mehndi sangeet $\left(49^{\prime} 14^{\prime \prime}-52^{\prime} 12^{\prime \prime}\right)$. Nevertheless, it is in the dance that she choreographs for the song "Chunari, Chunari" that she decides to perform alone a type of dance that is designed for a couple because she has been bumped by Rahul (who says to her that he cannot dance Indian songs because he can only dance as if he was in a pub in Melbourne, 1h22'24') and Varun (who is overreacting against her because his father has threatened him with having to go to boarding school if he continues dancing, $\left.1 \mathrm{~h} 12^{\prime} 10^{\prime \prime}\right)$. Here, Ayesha takes up a combative attitude instead of adopting the role of mourning lady that could have been expected by the South Asian community as she has been rejected twice. She starts performing alone with great strength while trying to make the guests enjoy the festive message of the song which talks about how a girl wants to use her chunari (veil or end part of a dress used by women to cover their faces) to flirt and tie her lovers instead of covering her face with it.

Ayesha performs with great splendour while she subverts the old message attached to the song, which had already appeared in Indian David Dhawan's movie Biwi No1 to illustrate how a man could be dating three different girls and the three of them should be waiting for him. As an alternative, Ayesha proves that a woman can stand alone and defy social norms.

In this festive atmosphere, we see Sikh, Muslim and Hindu members of the family joining Ayesha in a celebration that ignores religious differences (1h25'). Besides, Adit feels empowered to leave with her bridegroom Hemant (1h25'59') to spend the night alone as now they have defied their families' expectations and Aditi has confessed her affair with Vikram and Hemant has forgiven her. Furthermore, this dance empowers Ria to accuse Uncle Tej in front of the whole family as the dance has made her stand up to go and save her young cousin Aliya from him in the previously detailed scene (1h30'51").

Later, Indian-Australian Rahul jumps on stage to dance with Ayesha into a new hybrid dance style (classical South Asian and Melbourne pop-rock style) because his mother has mumbled to him that if he wants to be with Ayesha, he will have to show "a combative attitude in life" (1h26'54"). Furthermore, Alice (the servant of the family) has dressed up for the occasion and has been invited by Dubey, the wedding planner, to dance with him. Consequently, the dance scene illustrates the subversion of different religions and economic class backgrounds as we see different religious groups and social classes dancing together, the overcoming of fear by both Aditi and Ria (as explained in the previous section) and the illustration of an effort to struggle for the person who one truly loves as in the case of Ayesha, Rahul, Alice and Dubey.

Thus, this dance scene allows a transformation in the Verma family because they embrace the hybridity opened in the diaspora space for them by celebrating together this ecstatic dance without deferring to the different cultural and economic backgrounds of the guests. Accordingly, Argentinian dance therapist María Fux recognises that "dance can neither be far from the society it dwells nor from the daily problems of the people because dance cannot be a privilege but a tool to comprehend and educate" $(9$, my translation).

At this juncture, dance is an artistic language through which characters have understood their identities and the new paths that can be open for them and by them in the diaspora space if they decide to subvert old ideas imposed by both the empire and themselves. Consequently, dance is not only being used by the women to subvert race 
and gender inequality but also to empower women to rise up and collaborate together against the patriarchal order that exists. Bearing this feminist commitment in mind, dance allows women to create a web of collaboration and community identification on the way to gender equality. Accordingly, US dance professor Ann Daly states that dance is a perfect feminist language because it allows "the empowerment of women through their own body" (2). Therefore, if dance has a transformative power for characters and dance enhances a change of consciousness for both the performer and the audience, then women can connect with their own power through dance and defy the structures of gender inequality imposed on them.

This empowerment of women through a new representation of South Asian women is what Mira Nair promotes in her postcolonial version of William Makepeace Thackeray's novel Vanity Fair (1823). In fact, Mira Nair's telling of the British classic turns the negative image of Becky Sharp in Thackeray's writing into a heroine. Besides, Mira Nair includes explicit visual references to India when in the novel Thackeray only offered Orientalist portrayal of the colonies. Spanish Professor Ana Moya illustrates this point when she states: "Mira Nair rescues both women and the colonies from the periphery they occupy ... [and so] the margins ultimately replace the centre in Nair's refreshing reading of Becky Sharp" (85). In this sense, Nair's film (2004) describes the submission of gender and class and the subjugation of India to the British Empire. Similarly, Ana Moya has studied how Nair "feminises" Becky (73) to offer a new reading of the character.

Mira Nair portrays Becky Sharp as the heroine that, quoting Thackeray's original title Novel without a Hero, the original novel lacks. Nair displays Becky Sharp as a free woman who does not depend upon her family or husband and who, unlike in previous cinematographic versions, survives physically and economically without losing herself to vice, corruption or a marriage that she does not want. By so doing Nair gives a choice to Becky Sharp to redeem herself from the original novel and those cinematographic versions that had described her as a wicked prostitute and a bad mother. ${ }^{5}$ Actually, Nair states that, when she read the novel at high school, "Becky was the most memorable for me. She was a woman who was like us. She had been dealt cards by society but wanted to make her own deck" (2005). So, Nair reverses the role given to Becky and represents her as a woman who challenges the limitations imposed by society by class and gender.

Likewise, in Nair's version, Becky complains that it is difficult for women to explore new places $\left(7^{\prime} 54^{\prime \prime}-8^{\prime} 04^{\prime \prime}\right)$ as well as Becky criticises the limited roles of women as wives as she explains to Amelia: "We are soldiers' wives and we live with uncertainty"

5 Previous remarkable adaptations of Vanity Fair that did not change the role of Becky Sharp and so represented her as a sinful and shameful woman. $\left(1 \mathrm{~h} 15^{\prime} 04^{\prime}\right)$. Later, she denounces that the submissive and passive role of women is partly a consequence of the lack of women's commitment with struggle as she proclaims: "Of course is women the ones who keep the doors closed. They do not like outsiders to discover that there's nothing behind" (1h37'34').

Nair ridicules the lack of understanding shown by the Victorian society and juxtaposes Becky's desire to know about the world. Nair defines through Becky's dance and her group choreography a final subversion for the character where she becomes a woman who, in Mira Nair's own words, does not care about what other people think (as qtd. in Porter Phinzy 9). Actually, Becky subverts the whole scene entitling her dance the "Zenana ${ }^{6}$ Ballet" (1h48'56"-1h51'18") because she performs a dance where she leads a sexual revolution against men's control through their own intelligence and tricks (1h50'-1h51'18'). Nair portrays Becky as a woman who, through her dance, denounces the chauvinist aristocracy and high class of the nineteenth century and subverts the rules that are socially expected within a zenana. Instead, Becky carries out a rebellion where women can dance with a South Asian style to reclaim a place for themselves as slaves that break their chains in front of the very same King of England $\left(1 \mathrm{~h} 51^{\prime} 9^{\prime \prime}\right)$. The parallelism with the ongoing British invasion in India at those times is clear and how women disrupt their shackles can be linked to how Indian people would try to fight and defeat British means of colonization.

Thence, Mira Nair offers a new definition of Becky as an independent human being that matches the individual and group empowerment of other characters in Nair's films such as Mina in Mississippi Masala (1991) or Ashima in The Namesake (2006), characters that should be analysed in future studies as there is not enough space in the present publication. Why? Because they encourage a sorority among women so that women, as individuals and a group can talk, denounce share and lead paths ahead. In this sense, it is through the language of dance that the female characters get together, express themselves with total freedom.

\section{CONCLUSION}

Thus, it is through dance that Nair's films offer a new platform for women to start anew and in which they can turn from submissive women into active dwellers of the diaspora space and the homelands that do have a different (meaning an active and new) role to play. Mira Nair enables women to have a different role and so they allow the female characters in her hybrid narratives to join a feminist commitment towards an equal world where women empower themselves against gender and patriarchal burdens to interweave a nourishing space of collaboration. This place of association

6 Places reserved for women in a household and public buildings so that women can be secluded from social and public life.

Revista Internacional de Culturas y Literaturas, octubre 2016 
facilitates the cultural hybridity of the characters in the films to be portrayed so that the hybrid audiences of Nair's films create an empathetic relation with the female characters to understand the subversive possibilities granted in the diaspora space to attain a much more solidary society.

Accordingly, Nair offers a new definition for South Asian women on screen to show that there is a possibility of living together and fighting for gender equality while celebrating the making of cultural diversity that defines the inherent hope for equality granted in the diaspora space we all live within. And she does it with narrative elements from the South Asian performing arts to perform a change that, inherently, echoes old fights and always recurrent necessities to assess colonial and neo-colonia systems. Here, Nair's female characters show that women can do, dance and empower themselves. And this performance of the possibility of a much equal world is subversive because, as Henry Giroux states, "hope is subversive" (38).

\section{BiBLIOGRAPHY}

Balaswarati, T. (Bala), “Bala on Bharata Natyam” Sruti 5 (1984): 11-15.

Barba, E., La canoa de papel: tratado de antropología teatral. Madrid Catálogos, 1999 (1993)

Bharata M., Natyasastra (English translation with critical notes by Adya Rangacharya). New Delhi: Munshiram Manoharlal Publishers Pvt. Ltd., 2010. Print.

Biwi No.1 Dir. David Dhawan. TTV and Natwest, 1999. Chatterjea, A.,

Personal Interview. Barcelona, 1 Oct. 2011a.

Daly, A., "Unlimited Partnership: Dance and Feminist Analysis." Dance Research Journal, 23 1 (1991): 2-5.

Diego Sánchez, J., "Hybrid Cinemas and Narratives: Gender Representations in Women's Cinema of the South Asian Diaspora". Universidad de Salamanca, 2015.<http://gredos. usal. es/jspui/handle/10366/128136> Web. 8 Jan. 2016.

Dinesh, M. R. and Ramanathan, L., Bharatanatyam, Yesterday, Today, Tomorrow. New Delhi: Sujata Dinesh, 1985

Fux, M., Qué es danzaterapia. Preguntas que tienen respuesta. Madrid: Lumen Humanitas, 2005.

Gibbons, R., "Traditional Enactments of Trinidad: Towards a Third Theatre." M. Phil. Thesis, University of the West Indies, 1979.

Gilbert, H., "The Dance as Text in Contemporary Australia Drama: Movement and Resistance Politics." ARIEL 23 (1992): 133-48.

Gilbert, H, and Tompkins, J., Post-Colonial Drama. Theory, Practice, Politics. London and New York: Routledge, 1996.
Giroux, H. A., "When Hope is Subversive." TIKKUN 196 (2004): 38-39.

González Cruz, I., Natyasastra. Tratado fundamental de Poética, Composición y Artes Escénicas. Valencia: Letra Capital, 2013.

Maillard, C. and Pujol, Ó., Rasa. El placer estético en la tradición india. Madrid: Etnos: 1999. Massey, R., India's Kathak Dance Past, Present Future. New Delhi: Shakti Malik, Abhinav Publications, 2014 (1999).

Mississippi Masala. Dir. Mira Nair. Mirabai Films, 1991. DVD, 2008.

Morcom, A., Illicit Worlds of Indian Dance. Cultures of Exclusion. Oxford: Oxford University Press, 2014.

Moya, A., "The Politics of Re-presenting Vanity Fair: Mira Nair's Becky Sharp." ATLANTIS. Journal of the Spanish Association of Anglo-American Studies. 322 (December 2010): 73-87.

Monsoon Wedding. Dir. Mira Nair. IFC prdocutions, Mirabai Films, Keyfilms Roma, Pandora Filmproduktion, Paradis Films, Baron Pictures (II), Delhi Dot Com, 2001. DVD. 2007.

Nair, M., "Kama Sutra: an interview with Mira Nair." Online Daily the University of Washington. 13 Mar. 1997. <http://dailyuw.com/archive/1997/03/13/imported/kamasutra-interview-mira-nair>. Web. 24 Feb. 2005.

Nuir, J. K., Mercy in Her Eyes. The Films of Mira Nair. New York: Applause Theatre \& Cinema Books, 2006

O'Shea, J., At Home in the World: Bharata Natyam on the Global Stage. Connecticut: Wesleyan, 2007.

Porter Phinzy, C., "Subtle Subversion in Indian Cinema: Mira Nair's Use of British Orientalism in Vanity Fair." Modern Art Asia. 12 (November 2012): 1-16.<https://www.academia. edu/2398594/_Subtle_Subversion_in_Indian_Cinema_Mira_Nairs_Use_of_British Orientalism in_Vanity_Fair> Web. 12 Jun. 2016

Rangacharya, A., Natyasastra. English Translation with Critical Notes. New Delhi: Munshiram Manoharlal Publisheres Pvt. Ltd., 2010.

Roychowdhury Dasgupta, S., Personal Interview. Madrid, June 2014.

Sarabhai, Mrinalini. The Sacred Dance of India. Bombay: Bharatiya Vidya Bhaven, 1979.

Savarese, N., "The Experience of the Difference: Eurasian theatre, an Ancient Tradition of Performance and Theory." The Dramatic Touch of Difference: Theatre, Own and Foreign. Eds. Josephine Riley Fischer-Lichte and Michael Gissenwehrer. Tübingen: Gunter Narr Verlag Tübingen, 1990. 43-48

Sklar, D. S., "Dance Ethnography” in Dance Research Journal 231 (1991): 6-10. 
Tagore, R., Natir Puja (The Court Dancer) in Two Buddhist Plays. Kolkata: Writer's Workshop, 1993b (1932). 7-61.

The Namesake. Dir. Mira Nair. Dir. Mira Nair. Fox Searchlight Pictures, Cine Mosaic, Entertainment Farm (EF), Cinem Mosaic, Mirabai Films, UTV Motion Pictures, 2006. DVD. 2007.

Vanity Fair. Dir. Mira Nair. Focus Features, Franada Film Production, Epsilon Motion Pictures, Tempesta Films, 2004. DVD. 2005.

Vatsyayan, K., The Square and the Circle of the Indian Arts. New Delhi: Roli Books International, 1983.

Winton-Henry, C., Dance--The Sacred Art: The Joy of Movement as Spiritual Practice. Woodstock (VT): SkyLight Paths Publishing, 2009. 